\title{
ŠVČ. MERGELĖS MARIJOS VAIDMUO POPIEŽIAUS PRANCIŠKAUS GYVENIME IR MOKYME
}

\section{Remigijus Oželis}

Klaipèdos universitetas

\begin{abstract}
Anotacija
Jèzus, Dievo Sūnus, per kuri visa sukurta, susijungè su žeme, igydamas žmogiška pavidala Mergelès Marijos ịsčiose. Tad Bažnyčioje kreipiamasi i Mariją kaip Motina prašant užtarimo ir globos. Popiežius Pranciškus yra ypač pasišventęs Švč. Mergelei Marijai. Šventasis Tèvas Pranciškus akcentuoja, kad Marija rüpestingu žvilgsniu lydinti Jèzu, vykdantị savo misija, visada rodo Sūnu Jèzu, o ne save. Straipsnyje aptariami popiežiaus Pranciškaus pasišventimo Švč. Mergelei Marijai ir mokymo apie ją aspektai. PAGRINDINIAI ŽODŽIAI: Švč. Mergele Marija, popiežius Pranciškus, Bažnyčios Motina.
\end{abstract}

\begin{abstract}
Jesus, the Son of God, through whom all things were created, united with the world when taking on a human body in the womb of Virgin Mary. Therefore, the Church addresses Mary as Mother while praying for protection and care. Pope Francis is particularly devoted to the Blessed Virgin Mary. The Holy Father Francis emphasises that Mary, while carefully watching Jesus fulfilling His mission, always points to Her Son Jesus and not to Herself. The article discusses the aspects of Pope Francis's devotion to the Blessed Virgin Mary and his teaching about the Blessed Virgin Mary. KEY WORDS: the Blessed Virgin Mary, Pope Francis, Mother of the Church.
\end{abstract}

\section{Ižanga}

Krikščioniško tikejjimo centras yra Jėzaus, iš moters gimusio Dievo Sūnaus, išpažinimas. Jèzaus pradèjimas Mergelëje Marijoje yra dieviškosios sūnystès ženklas. Švenčiausioji Mergelè Marija per savo santykị su Jėzumi artimai susisieja su krikščionių tikèjimu (Popiežius Pranciškus, 2013, nr. 59). Jėzų pagimdžiusi Mergelė Marija yra „malonėmis apdovanotoji“ (Lk 1, 28). Moteris krikščionių tikejjime tampa vilties ženklu, vedančiu prie Dievo. Marijos asmenyje išreikšta provaizdinè moters esybé, grynasis žmogaus ir Bažnyčios pavidalas. Ieva, pirmoji moteris, pramotè, visų gyvųjų motina, iš esmès gimdè mirčiai, o Marija pagimdè Gelbetoją, kuris prisikèlè ir nešè gy- 
vybę, taip tapo išsipildymu to, ką reiškia žodis Ieva, ką reiškia moters ir jos vaisingumo pažadas. Marija tampa motina to, kuris yra gyvenimas ir teikia gyvybę, ji tampa gyvybès ir gyvujų motina (Ratzinger, 2010, p. 253). Dievo ir Bažnyčios Motina. Apaštališkajame paraginime „Evangelii gaudium“ popiežius Pranciškus sako: „Kaskart, kai pažvelgiame ị Mariją, įtikime [motinystès] revoliucine švelnumo ir meilès galia“ (Šventasis Tèvas Pranciškus, 2014, nr. 288). Motinos Marijos švelnumo ir meilès revoliuciją regime popiežiaus Pranciškaus gyvenimo veikloje ir mokyme.

Šiame straipsnyje aptariami Švč. Mergelès Marijos vaidmens akcentai popiežiaus Pranciškaus gyvenime ir mokyme. Tyrimo o b j e k t a s : Švč. Mergelès Marijos asmuo, remiantis popiežiumi Pranciškumi. Straipsnio tiks la s : aptarti Švč. Mergelès Marijos asmens vaidmenị popiežiaus Pranciškaus gyvenime ir mokyme.

Užda vi n ia i : 1) pristatyti Švč. Mergelès Marijos vaidmens reiškimąsi popiežiaus Pranciškaus gyvenime; 2) aptarti Švč. Mergelès Marijos gyvenimo aspektus Šventojo Tèvo Pranciškaus mokyme.

M e t o d a i : literatūros sisteminio tyrimo, analizès, interpretavimo ir apibendrinimo. Kadangi tiriama Švč. Mergelès Marijos vaidmens raiška popiežiaus Pranciškaus gyvenime ir mokyme, tyrime remiamasi popiežiaus Pranciškaus raštais ir raštais apie popiežių Pranciškų.

\section{1. Švč. Mergelès Marijos vaidmuo popiežiaus Pranciškaus gyvenime}

Šventojo Tèvo Pranciškaus herbe pavaizduoti popiežiški simboliai: mitra, raudonos mitros juostos, du sukryžiuoti raktai ir mèlynas skydas. Skyde pavaizduota saulè, kurioje įrašyta monograma IHS (lot. Iesus Hominum Salvator - Jèzus, žmonių Gelbètojas), skydo apatinès dalies kairèje pavaizduota žvaigždè, kuri pagal krikščionišką tradiciją simbolizuoja Švč. Mergelę Mariją, Kristaus ir Bažnyčios Motiną (Popiežiaus Pranciškaus herbas ir moto, 2013; Gaeta, 2013, p. 33). Žvaigždè herbe, kaip Švč. Mergelès Marijos simbolis, išreiškia išskirtini Marijos vaidmenị Šventojo Tẻvo Pranciškaus gyvenime. 


\subsection{Pamaldumo Marijai praktikavimas}

Jorge Mario Bergoglio dar iki išrinkimo popiežiumi 2013 m. pasižymi ypatingu pamaldumu Švč. Mergelei Marijai. Būdamas arkivyskupu J. M. Bergoglio dažnai lankydavosi bažnyčiose, kurios pašvęstos Marijos garbei. Čia galima išskirti Luchano šventovę, esančią už septyniasdešimties kilometrų nuo Buenos Airių. Joje meldžiamasi Luchano Dievo Motinai, argentiniečių Madonai. J. M. Bergoglio visada apsilankydavo joje jos iškilmių dieną - gegužès 8-ają. Lankydavosi ir Kaakupès ir lūšnynų Dievo Motinos bažnyčiose.

1986 m. kun. J. M. Bergoglio, studijuodamas teologiją Vokietijoje, susipažino su pamaldumo ị Švč. Mergelę Mariją praktika, atrišančia mazgus. Šią praktiką ir to titulo Marijos paveikslą jis atvežè į Argentiną, kur ši maldingumo praktika labai išplito (Carello, 2018, p. 59-60; Vallely, 2015, p. 26, 51).

Kai jau būdamas vyskupu J. M. Bergoglio atvykdavo ị Romą, apsistodavo už penkiasdešimties metrų nuo Scrofos gatvès, kur stovi Šv. Augustino bažnyčia, kurioje yra Švč. Mergelès Marijos paveikslas. Kiekvieną rytą, prieš eidamas ị Vatikaną, vyskupas J. M. Bergoglio užeidavo ị bažnyčią pasveikinti su Marija, Piligrimų Madona (Popiežius Pranciškus, 2019, p. 113).

2013 m. kovo 13 d. išrinkus J. M. Bergoglio popiežiumi, jau pirmą ankstų rytą jis nuejjo ị Romos Didžiąją Švč. Mergelès Marijos baziliką, kur meldèsi prie Dievo Motinos, Salus populi Romani (Romos gyventojų Gelbètojos), ikonos. Ir toliau jis dažnai lankydavosi Didžiojoje Švč. Mergelès Marijos bazilikoje, čia meldèsi prie minètos Marijos ikonos, kuri priskiriama prie stebuklingų ikonų ir minima tarp penkių seniausių Marijos atvaizdų Romoje (Tornielli, 2017, p. 359). Šventojo Tèvo teigimu, „Bažnyčiai augti kaip tik ir padeda Švenčiausios Mergelès, Dievo Motinos, ikona“" (Pranciškus, 2018, p. 158). Popiežius Pranciškus šioje bazilikoje apsilanko prieš kiekvieną kelionę ir grižęs jos, meldžiasi prie Marijos ikonos, padeda gèlių puokštę (Popiežius meldèsi prie Marijos „Salus populi Romani“ atvaizdo, 2018). Šventasis Tèvas sako: „Tikrai nuostabu žiūrèti ị Madoną, tačiau dar nuostabiau leisti jai žiūrèti ị tave, leisti žiūrèti ir išsakyti jai viską, žinant, kad esi matomas“ (Popiežius Pranciškus, 2019, p. 73). Šventasis Tẻvas Pranciškus - nuoširdžiai Švč. Mergelei Marijai atsidavęs popiežius. 
Popiežius Pranciškus pažymi ir Švč. Mergelès Marijos apsireiškimų vietas: Lurdą, Fatimą, Gvadelupę, kur, pasak Šventojo Tẻvo, ,Marija žvelgia ir sako: „Nebijok. Aš tavo motina.“ Tokia patirtis man labai svarbi ir iškalbinga“"(Popiežius Pranciškus, 2019, p. 105-106). I Medžiugorję, kuri beveik keturis dešimtmečius garsejja kaip Bažnyčios nepatvirtintų Švč. Mergelès Marijos apsireiškimų vieta, popiežius Pranciškus paskyrè arkivyskupą Henryk'ą Hoser'i ypatinguoju apaštališkuoju vizitatoriumi (Popiežius skiria nuolatinị apaštališkaji vizitatorių Medžiugorje, 2018). Tai vienas iš popiežiaus Pranciškaus pasišventimo Švč. Mergelei Marijai akcentų.

Apaštališkajame paraginime „Evangelii gaudium“, viename pirmujų savo, kaip pontifiko, dokumentų, popiežius Pranciškus rašo, kad ,per ịvairias pamaldumo Marijai formas, paprastai susijusias su tam tikromis šventovèmis, [Marija] dalyvauja kiekvienos tautos, prièmusios Evangeliją, istorijoje ir tampa tos tautos istorinès tapatybès dalimi. (...) Ten, šventovèse, galima stebėti, kaip Marija suburia apie save vaikus, kurie, nepaisydami nuovargio, atkeliavo, kad ją pamatytų ir būtų jos pamatyti“ (Šventasis Tèvas Pranciškus, 2014, nr. 286).

\subsection{Rožinio malda}

Popiežius Pranciškus yra atsidavęs Švč. Mergelei Marijai per Rožinio maldą. Jis pats kalba apie patirtị, kai naujai suskambẻjo popiežiaus Jono Pauliaus II Apaštališkojo laiško „Rosarium Virginis Mariae“ žodžiai: „Rožinis lobis, kurị reikia atrasti. (...) Tokia lengva ir kartu tokia turtinga malda tikrai nusipelno, kad ją iš naujo atrastų krikščionių bendruomenè“" (Jonas Paulius II, 2002, nr. 43). Tai patirtis, kuri J. M. Bergoglio gyvenime ypač išryškino Rožinio maldos, skirtos Švč. Mergelei Marijai, svarbą. Apie šią patirti J. M. Bergoglio sako:

„Tai buvo galbūt 1985 metai. Vieną vakarą nuvykau kalbèti Rožinio, kuriam vadovavo Šventasis Tẻvas [Jonas Paulius II]. Jis klūpėjo visų priekyje. Buvo daug žmonių. Mačiau Šventaji Tèvą iš nugaros ir palengva pasinèriau ị maldą. Nebuvau vienas. Meldžiausi su Dievo tauta, kuriai priklausiau aš ir visi ten dalyvavę asmenys, vadovaujami savo Ganytojo. 
Besimelsdamas išsiblaškiau žvelgdamas ị Popiežiaus [Jono Pauliaus II] figūrą: jo pamaldumas, jo pasišventimas buvo liudijimas! Laikas bègo ir pradejjau vaizduoteje matyti jaunajj kunigą, seminaristą, poetą, darbininką, Vadovicų paaugli... tokioje pat pozoje, kokioje jis tada buvo kalbèdamas Rožinį, „Sveika Mariją“ po „Sveika Marijos“. Jo liudijimas pribloškè. Pajutau, kad tas žmogus, išrinktas vadovauti Bažnyčiai, ejjo keliu, vedančiu iki pat jo dangiškosios Motinos, keliu, kuris prasidejjo vaikystėje. Tuomet supratau, kokie svarūs buvo žodžiai, Gvadalupès Motinos ištarti šv. Jonui Diegui: „Nebijok, nejaugi nesu tavo motina?“ Tuomet perpratau Marijos buvimą popiežiaus gyvenime“ (Popiežius Pranciškus: Rožinis yra lobis, kurị reikia atrasti, 2013).

Taip popiežius Pranciškus, ịkvėptas popiežiaus Jono Pauliaus II pavyzdžio, visą Rožinio maldą sukalba kasdien. Pasak Šventojo Tèvo Pranciškaus, Rožinis suartina su Švč. Mergele Marija, turejjusia ịveikti nedrąsą, kad priimtų Dievo jai skirtą misiją tapti Išganytojo motina - motina, kurios širdis bus perverta daugybès sopulių. Jis suartina mus su ja per Prisikèlimo džiaugsmą: visi Dievo pažadai jai buvo išpildyti. Rožinis suartina mus su ja per viltị, kad ir mūsų maldos bus išgirstos, kai kreipsimès ị Viešpatị savo reikalais (Rožinio malda su popiežiumi Pranciškumi, 2018, p. 1, 27). Tad popiežius Pranciškus ragina kalbèti rožinị kuo dažniau ir labai susitelkus. Maldingi rožinio slèpinių mąstymai gilina tikèjimą, padeda suvokti, kaip didieji tikèjimo ịvykiai susiję su kiekvieno žmogaus gyvenimu, ịsisąmoninti, kad Dievas kviečia žmogų dalytis Jo meile ir gyvenimu su kitais (Rožinio malda su popiežiumi Pranciškumi, 2018, p. 32).

Popiežius Pranciškus pirmaisiais savo pontifikato metais spalio 12 dieną, švęsdamas Tikejjimo metų „Marijos dieną“, vadovavo šv. Mišioms Šv. Petro aikštėje Vatikane, kur po šv. Mišių perskaitė Pasiaukojimo Švč. Mergelei Marijai maldą ir tos pačios dienos pavakare kalbejjo Rožinio maldą Romos Didžiojoje Švč. Mergelès Marijos bazilikoje. Rožinio apmąstyme popiežius Pranciškus kvietė ịsižiūrèti ị Marijos žvilgsnị: „, „ ką žvelgia Mergelė Marija? Žvelgia ị mus visus, ị kiekvieną iš mūsų. Žvelgia kaip Motina, švelniai, gailestingai, su meile. Kai esame pavargę, praradę drąsą, prislègti problemų, žvelgiame ị Mariją, jaučiame jos žvilgsnị, kuris sako mūsų širdžiai: „Stiprybès, vaike, aš esu čia, kad tave paremčiau!“ Kai jaučiame savo silpnumo ir 
nuodėmių svorị, žvelgiame ị Mariją, kuri sako mūsų širdžiai: „Kelkis, eik pas mano Sūnų Jėzų, jame surasi gailestingumą, svetingumą ir naujų jègų tęsti savo kelią" (Marija, Bažnyčios Motina - Kristaus ir Bažnyčios slëpinio supratimo raktas, 2018). Taigi popiežius kviečia su Marija artėti prie Jėzaus.

Popiežius Pranciškus Vilniaus Aušros Vartų Švč. Mergelès Marijos, Gailestingumo Motinos, koplyčioje prieš Rožinio maldą kalbejjo: „Mąstydami Rožinio slëpinius prašykime Jos, kad būtume bendruomene, skelbiančia Kristu Jėzu, mūsu viltį, ir kurtume Tẻvynę, galinčią priimti visus, gebančią iš Mergelès Motinos priimti dialogo ir kantrumo dovanas, artumo, mylinčio atleidimo ir nesmerkiančio svetingumo dovanas; Tèvynę, kuri pasirenka statyti tiltus, bet ne sienas, kuri mieliau renkasi gailestingumą, bet ne teisimą" (Popiežiaus Pranciškaus vizitas Lietuvoje, 2018, p. 18).

\subsection{Marijos, Bažnyčios Motinos, šventė}

Marija - moteris, Juozapo žmona, visa kupina Šventosios Dvasios, todèl - Motina Kristaus ir Motina Bažnyčios. Bažnyčios motiniškumas kyla iš Marijos motiniškumo, Bažnyčios švelnumas kyla iš Marijos švelnumo (Popiežius Pranciškus, 2019, p. 110-111; Vallely, 2015, p. 371). Todèl popiežiui Pranciškui labai svarbu išryškinti Marijos, kaip Bažnyčios Motinos, vaidmenị.

Dievo kulto ir sakramentų kongregacija 2018 m. vasario $11 \mathrm{~d}$. išleido dekretą, kuriuo skelbiamas popiežiaus Pranciškaus nutarimas ị Visuotini Romos kalendorių ịtraukti Švč. Mergelès Marijos, Bažnyčios Motinos, minejimą ir šiuo titulu kasmet pagerbti Švenčiausiają Mergelę pirmadienį po Šventosios Dvasios Atsiuntimo (Sekminių) iškilmès. Šis privalomas minèjimas turètų padèti atminti, kad siekiant tobulèti gyvenant krikščioniškai būtina vienytis su Kryžiaus slëpiniu, eucharistine Kristaus auka ir Mergele Marija - Atpirkejjo ir visų atpirktujų Motina. Marija, stovėdama po kryžiumi (plg. Jn 19, 25), prièmè savo Sūnaus meilès testamentą ir per mylimajị Jèzaus mokinį Joną tapo visų žmonių motina Bažnyčioje, kurią pagimdè Kristus, ant kryžiaus atiduodamas Dvasią. Nuo İsikūnijimo momento būdama susivienijusi su savo Sūnumi, Švenčiausioji Mergelè leidosi visiškai ịtraukiama ị Jè- 
zaus misiją, kuri Kryžiaus papejdeje tapo ir jos misija: kad būdama Bažnyčios Motina bendradarbiautų gimdant Dvasioje ir tikejjime naujus Dievo sūnus ir dukras. Kristus savo ruožtu visus žmones paskyrẻ savo meilès Motinai paveldètojais, kad visi ją su meile priimtų (Congregation for Divine Worship and the Discipline of the Sacraments, 2018; Lietuvos Vyskupų Konferencijos Liturgijos komisijos informacija dèl Švč. Mergelès Marijos, Bažnyčios Motinos, liturginio minèjimo, 2018, p. 15; Popiežius Pranciškus, 2019, p. 7-8; Vallely, 2015, p. 225).

Marija vadinama Bažnyčios Motina nuo seniausių krikščionybės laikų, bet oficialiai šị titulą 1964 m. suteikè popiežius Paulius VI. Nuo tada Vatikane ir kai kur kitur Marijos, Bažnyčios Motinos minejjimas buvo švenčiamas spalio 12 dieną (Marija, Bažnyčios Motina - Kristaus ir Bažnyčios slëpinio supratimo raktas, 2018). Visuotinė Marijos, Bažnyčios Motinos, šventè skatina „kurti ir puoselèti bendras erdves, kurios stiprintų priklausymo, šaknu pojūtį, kurios miestus paverstų tikraisiais namais, bendruomenėmis, kurios sutelkia ir palaiko“ (Popiežius Pranciškus, 2019, p. 43). Popiežius Pranciškus vidinį ryšị tarp Marijos, Bažnyčios ir kiekvieno tikinčiojo, išreiškė Izaoko Žvaigždiškio žodžiais: „Kas dieviškuosiuose Raštuose bendrai sakoma apie mergelę ir motiną Bažnyčią, konkrečiai galioja Mergelei Marijai. Panašiai galima sakyti, kad kiekviena tikinti siela yra Dievo Žodžio sužadėtinė, Kristaus motina, duktẻ ir sesuo, mergelẻ ir vaisinga motina. Kristus, praleidęs devynis mènesius Marijos įsčiose, Bažnyčios tikèjimo tabernakulyje lieka iki amžiu pabaigos, o tikinčios sielos pažinime ir meilëje - per amžių amžius“ (Šventasis Tèvas Pranciškus, 2014, nr. 285). Marija yra Bažnyčios Motina. „Žodis motina (mater) susijęs su žodžiu materija. Per savo Motiną dangaus Dievas, begalinis Dievas tapo mažu, tapo materija, ne tik kad būtų su mumis, bet kad būtų kaip mes“ (Popiežius Pranciškus, 2019, p. 75-76).

Apaštališkajame paraginime „Evangelii gaudium“ popiežius Pranciškus teigia: „Keliais varganais vystyklais ir meilès gausa Marija paverte gyvulių tvartą Jèzaus namais. (...). Būdama visų motina, ji yra vilties ženklas tautoms, kenčiančioms gimdymo skausmus, kol subręs teisingumas. Misionierè, prisiartinanti prie mūsų ir lydinti mus gyvenimo kelyje bei savo motiniška meile atverianti širdis tikejjimui“ (Šventasis Tẻvas Pranciškus, 2014, nr. 286). 


\section{2. Švč. Mergelė Marija popiežiaus Pranciškaus mokyme}

Ypatingas dėmesys Švč. Mergelei Marijai popiežiaus Pranciškaus gyvenime skatina tai išreikšti ir savo mokyme. Kalbèdamas apie Švč. Mergelę Mariją Šventasis Tèvas sako: „Nuo pat gimimo iki Apreiškimo, susitikimo su Viešpaties Angelu, ji yra paprasta, normali mergaitè, mergina, kaip ir dabartinès merginos. Negaliu sakyti, kad iš miesto, nes ji iš miestelio, bet, pabrèžiu, paprasta, normali, normaliai išauklèta, pasirengusi tekèti, sukurti šeimą. Taip pat žinau, kad ji buvo pamėgusi Šventaji Raštą. (...) Dirbo, eidavo apsipirkti, padejo Sūnui, padejjo vyrui - viskas labai normalu“ (Popiežius Pranciškus, 2019, p. 16-17). Tačiau „Mergelè Marija susitikimą su Jėzumi patyrè nepakartojamu būdu“ (Pranciškus, 2018, p. 32). Toliau apžvelkime, ką popiežius Pranciškus akcentuoja kalbėdamas apie Švč. Mergelę Mariją.

\subsection{Angelo apreiškimas Marijai - „malonėmis apdovanotoji“6 $($ Lk 1, 28)}

Marija, kaip liudija Evangelija pagal Luką, niekuo ypatingu neišsiskyrè, buvo iš paprastos šeimos, kukliai gyveno Nazarete, beveik nežinomame miestelyje. Nebuvo įžymybè: kai ją aplankè angelas, tą dieną to nesužinojo niekas. Tačiau Marijos gyvenimas nebuvo ramus, Evangelija pagal Luką byloja, kad ji sumišo (Lk 1, 29), o angelui pasitraukus (Lk 1, 38) rūpesčių ir nerimo tik padaugèjo (Popiežius Pranciškus, 2019, p. 22).

Angelas sveikina Mergelę Mariją: „Sveika, malonėmis apdovanotoji!“ (Lk 1, 28). Ką reiškia „malonėmis apdovanotoji“ arba, kaip sakoma maldoje „Sveika, Marija“, „malonès pilnoji“? „Marija yra pilna Dievo esaties. O jeigu ji visiškai užpildyta Dievo, joje nèra vietos nuodèmei. Tai stulbinamas dalykas, nes viskas pasaulyje, deja, yra apkressta blogiu. Net didieji šventieji buvo nusidejèliai ir netgi patys gražiausi dalykai yra paliesti blogio: viskas, išskyrus Mariją. Ji vienintelè žmonijos nesutepta, sukurta tyra, kad savuoju „taip“ tobulai priimtų Dievą, ateinantị ị pasaulị pradèti naujos istorijos“ (Popiežius Pranciškus, 2019, p. 20-21). „Gailestingumo žinią Dievas tarsi pradeda iš naujo, ir pradeda nuo moters. Jaudina žinojimas, kad taip prasideda krikščionybë“ (Popiežius Pranciškus, 2019, p. 7). Dievas „imasi iniciatyvos 
ir nusprendžia ịžengti ị mūsų namus, kaip padarè su Marija“ (Pranciškus, 2018, p. 175).

Popiežius Pranciškus sako: „Atèjus laiko pilnatvei, Dievas tarẻ Žodị Marijai, ir ji visa esybe prièmé ji i i savo širdị, kad jis joje taptų kūnu ir iš jos gimtų kaip šviesa žmonèms“ (Popiežius Pranciškus, 2013, nr. 58). Ji besąlygiškai ištarè „taip“ Dievo valiai, „tebūna man, kaip tu pasakei“ (Lk 1, 38). Dèl šio „taip“ Jèzus pradèjo savo žygị žmonijos keliais, pradejo Marijoje, pirmuosius mėnesius praleisdamas motinos įsčiose: nepasirode iš karto suaugęs ir tvirtas, nuejjo visą žmogaus raidos kelią. Tapo viskuo panašus i mus, išskyrus nuodèmę. Todèl pasirinko Mariją, vienintelę būtybę be nuodèmès, nekaltai pradètają. Evangelijoje ji apibendrintai vadinama „malonèmis apdovanotaja“ (plg. Lk 1, 28), tai yra malonès pilnaja. Tai reiškia, kad joje, iškart malonès pripildytoje, nèra vietos nuodèmei (Popiežius Pranciškus, 2018 B, p. 60). Ji be gimtosios nuodèmès. Marija atsiliepia ị Dievo kvietimą sakydama: „Štai aš Viešpaties tarnaite““ (Lk 1, 38). Jos „taip“ besąlygiškas, totalus, visam gyvenimui, be išlygų. Tai pats svarbiausias „taip“ istorijoje, nuolankus „taip“, anuliuojantis išdiduji žmonijos pradžios „ne“, ištikimybès „taip“, gydantis nepaklusnumą, atvirumo „taip“, naikinantis nuodèmès egoizmą (Popiežius Pranciškus, 2018 B, p. 61).

Gilinantis ị angelo apreiškimą Marijai Šventasis Tèvas kviečia: „Pamąstykime: kokị „,taip“ aš šiandien turěčiau ištarti Dievui? Pamąstykime visi. (...) Savyje išgirsime Viešpaties balsą, šio bei to prašanti, - žengti žingsnị i priekį. Tikiu ị Tave, Tavimi viliuosi, Tave myliu; teịvyksta per mane Tavo geroji valia. (...) Didžiadvasiškai ir pasitikèdami, kaip Marija, ištarkime šiandien kiekvienas tokị asmenini „taip“ Dievui“ (Popiežius Pranciškus, 2018 B, p. 62).

\subsection{Marijos apsilankymas pas Elzbietą - „tu labiausiai palaiminta“ (Lk 1, 42)}

Po Apreiškimo Marija pirmiausia aplanko gerokai vyresnę savo giminaitę Elzbietą. Tai meilès veiksmas. Popiežius Pranciškus sako: „Aplankyti reiškia atverti duris, neužsisklęsti savo butuose, eiti kitų link“ (Pranciškus, 2018, p. 138). Marija yra atvira, neužsisklendusi. Marijos ejjimas pas Elzbietą - tai „komunikavimas kaip artumo atradimas ir statydinimas“ (Pranciškus, 2018, 112 
p. 128). Marija yra tikèjimu gyvenanti ir keliaujanti moteris, o jos išskirtinè tikèjimo kelionė yra nuolatinis atramos taškas Bažnyčiai. Tikèjimo kelyje ji leidosi Dvasios nuvedama ị tarnavimo bei vaisingumo dalią (Šventasis Tèvas Pranciškus, 2014, nr. 287). Sutikdama Mariją Elzbieta „balsiai sušuko: „Tu labiausiai palaiminta iš visų moterų ir palaimintas tavo įsčių vaisius!“ (Lk 1, 42). Marija palaiminta, nes gimè be kaltès, be nuodèmès. Buvo išrinkta tapti Motina, suteikti kūną Dievui, argi tai ne palaiminimas? (Popiežius Pranciškus, 2019, p. 37).

Pirmi Marijos ištarti žodžiai apsilankius pas Elzbietą: „Mano siela šlovina Viešpatį“ (Lk 1, 47). Tai šlovinimo giesmè ne tik už tai, kad išsirinko ją, bet ir padèka Dievui už visą išganymo istoriją (Popiežius Pranciškus, 2019, p. 33). „Marija šlovina Dievą. (...) Šlovinti Dievą - išeiti iš savęs, taigi nelengvas dalykas mūsų egoizmui“ (Popiežius Pranciškus, 2019, p. 104). Žvelgdami ị ją atrandame, kad ta, kuri šlovino Dievą, nes jis ,numeta galiūnus nuo sostų“ ir „turtuolius tuščiomis paleidžia“ (Lk 1, 52-53), yra ta pati, kuri mūsų teisingumo paieškoms suteikia namų šilumos. Nazarete ji yra maldos ir darbo moteris, taip pat moteris, pasirengusi nedelsdama „skubiai“ $(L k$ 1, 39) iškeliauti iš kaimo padèti kitiems (Šventasis Tèvas Pranciškus, 2014, nr. 288).

Šventasis Tẻvas Pranciškus, apmąstydamas Marijos apsilankymą pas Elzbietą, sako: „Kupina Kristaus artumo, tu pradžiuginai Joną Krikštytoją, priversdama ji šoktelèti savo motinos ịsčiose. Virpèdama iš džiaugsmo, giedojai apie Viešpaties įstabius darbus. (...) Suteik šventos drąsos ieškoti naujų būdų, kad visus pasiektų neblèstanti grožio dovana. Išklausymo ir kontempliacijos Mergele, meilès Motina, amžinųjų vestuvių Nuotaka, užtark Bažnyčią, kurios esi tyriausiasis paveikslas, kad ji niekada savyje neužsisklęstų ir nenustotų aistringai statydinusi Karalystès. (...) padèk suspindèti bendrystès, tarnystès, karšto ir dosnaus tikèjimo, teisingumo ir meilès vargšams liudijimui, kad Evangelijos džiaugsmas pasklistų po visą žemę ir nė vienam pakraščiui nestigtų jos šviesos“ (Šventasis Tẻvas Pranciškus, 2014, nr. 288). 


\subsection{Marijos tylus apmąstymas - „dẻmėjosi visus šiuos dalykus ir svarstė juos savo širdyje ${ }^{\text {“6 }}($ Lk 2, 19)}

Nuo pirmojo Marijos pasirodymo Evangelijų pasakojimuose jos asmuo paženklintas dramatiškumo. Nebuvo paprasta ị angelo kvietimą atsakyti „taip“, bet ji, dar jaunutė mergina, atsakè drąsiai, nors ir nežinojo, kas jos laukia. Anas „taip“ yra pirmas žingsnis ilgame klusnumo aktų sąraše, žyminčiame jos motinystės kelią. Marija Evangelijose parodoma kaip tyli moteris, dažnai nesuprantanti visko, kas aplink ją vyksta, tačiau širdyje apmąstanti kiekvieną žodị ir ịvykị (Popiežius Pranciškus, 2018 A, p. 74).

Evangelistas Lukas ,kalba apie Marijos atmintị, apie tai, jog ji visa, ką išgirdo ir pamatè, saugojo širdyje, kad žodis jos gyvenime duotų vaisių. Viešpaties Motina yra tobula tikèjimo ikona, pasak šventosios Elzbietos: „Laiminga įtikèjusi““ (Lk 1, 45)“ (Popiežius Pranciškus, 2013, nr. 58). „Marija dèmèjosi visus šiuos dalykus ir svarstè juos savo širdyje“ (Lk 2, 19). Dèmejjosi, dèjosi ị širdị, saugojo juos ten. Marija nekalba: visame pasakojime apie Jėzaus gimimą Evangelija nepateikia nè vieno jos ištarto žodžio. Motina yra susivienijusi su Sūnumi: Jèzus, kūdikis, žodžių netaria. Jis, Žodis, Dievo Žodis, kuris „,daugel kartų ir įvairiais būdais praeityje yra kalbèjęs“ (Žyd 1, 1), dabar, atejjus „laiko pilnatvei“ (Gal 4, 4), tyli. Dievas, prieš kurị nuščiūvama, yra vaikelis, kuris dar nekalba. Jo didybè bežodè, Jo meilès paslaptis atsiskleidžia per mažumą. Šis tylusis mažumas yra Jo byla. Jo pranešimas apie savęs dovanojimą. Motina vienijasi su Sūnumi ir slėpiniu tyloje (Popiežius Pranciškus, 2019, p. 76-77).

Evangelija pagal Luką skelbia, kad Marija dėmėjosi visus šiuos dalykus ir „svarste juos savo širdyje“. Kokius „tuos dalykus“? Džiaugsmus ir skausmus. Visų pirma tai Jėzaus gimimas, Juozapo meilè, piemenų apsilankymas, anos nakties šviesa. Bet ne tik: nežinia dèl ateities, pastogès nebuvimas, ,nes jiems nebuvo vietos užeigoje“ ( $\operatorname{Lk} 2,7)$, neviltis dèl atstūmimo, nusiminimas, kad Jèzų gimdyti teko tvartelyje. Viltis ir nerimas, šviesa ir sutemos - štai „tie dalykai“", kurie kaupėsi Marijos širdyje. Ji juos svarstė, ramiai apmąstė su Dievu širdyje. Nieko nepasilaikè sau, nepaskandino kartėlyje, neužsisklendè vienatvèje - viską pavedè Dievui. Pasitikèti ir yra dèmètis: neleidžiant 
gyvenimo užvaldyti baimei, nusivylimui ar prietarams, neužsidarant savyje, nesistengiant pamiršti. Visais klausimais bendraujant su Dievu (Popiežius Pranciškus, 2019, p. 77, 97). Marija moka atpažinti Dievo Dvasios pėdsakus didžiuosiuose įvykiuose ir tuose, kurie atrodo nepastebimi. Ji kontempliuoja Dievo slèpini pasaulyje, žmonijos istorijoje ir kasdieniame mūsų kiekvieno gyvenime (Šventasis Tèvas Pranciškus, 2014, nr. 288).

\subsection{Marija kreipia ị Jẻzų - „,darykite, ką tik jis jums lieps“ (Jn 2, 5)}

2015 m. rugsèjo 15ąą, Skausmingosios Mergelès Marijos minèjimo dieną, pasirašydamas Žinią 24-ajai Pasaulinei ligonių dienai, švęsimai 2016 m. vasario 11-ają, Lurdo Dievo Motinos liturginio minejjimo dieną, Šventasis Tèvas aptarė Galilejjos Kanoje vykusias vestuves, kuriose dalyvavo Jėzus su Marija. Vestuvių Kanoje metu Marija yra rūpestinga moteris, ji pamato sutuoktiniams iškilusią problemą: vynas, šventinio džiaugsmo simbolis, baigèsi. Išvydusi situaciją tam tikra prasme Marija padaro ją sava ir nedelsdama taktiškai ima veikti. Ji nelieka tik stebètoja, juolab nepuola aiškintis, kas kaltas, bet kreipiasi ị Jėzų išdèstydama jam ši keblų dalyką: ,Jie nebeturi vyno“ (Jn 2, 3). Ir kai Jèzus atsako jai, kad dar neatejo metas Jam apsireikšti (plg. Jn 2, 4), ji taria tarnams: „Darykite, ką tik jis jums lieps“ (Jn 2, 5) (Popiežius Pranciškus, 2015, p. 9).

„Darykite, ką tik jis jums lieps“ (Jn 2, 5) - paskutiniai Evangelijose užrašyti Marijos žodžiai. Šie paskutiniai Marijos žodžiai yra Motinos palikimas mums. Dievo Motina ir šiandienos žmogui sako: „Ką tik jis jums lieps - ką Jėzus jums lieps - darykite!“ Tai jos palikimas visų laikų žmonėms. Tai žodžiai, primenantys atsaką ị sandoros pažadus Izraelio tautos prie Sinajaus kalno: „Visa, ką tik Viešpats kalbejjo, darysime!“ (Iš 19, 8). Šiose vestuvėse sudaroma nauja sandora ir Viešpaties tarnams - visai Bažnyčiai - pavedama nauja misija: „Darykite, ką tik jis jums lieps!“ Tarnauti Viešpačiui - tai klausytis ir ịgyvendinti jo žodị. Tai paprastas, bet esminis Jėzaus motinos patarimas ir krikščionio gyvenimo planas. Semti iš indo reiškia patikèti save Dievo žodžiui, kad patirtum jo veikimo galią gyvenime (Popiežius Pranciškus, 2016, p. 23). 
Per vestuves Kanoje greta Jèzaus ir jo Motinos yra ir tie, kurie vadinami „tarnais“, Marija jiems nurodo: „Darykite, ką tik jis jums lieps“ (Jn 2, 5). Stebuklą, savaime suprantama, padaro Kristus. Vis dèlto, darydamas stebuklą, Jis pasitelkia žmogaus pagalbą, nori žmogaus bendradarbiavimo ir paprašo tarnų pripildyti indus vandens. Tarnai, pasitikėdami Marijos nurodymu, daro, ką liepia Jèzus. Tuo ir mums parodoma, jei mokèsime atsiliepti ị tos, kuri sako: „Darykite, ką tik jis jums lieps“ (Jn 2, 5), balsą, Jèzus mūsų gyvenimo vandenị visada pavers tauriu vynu (Popiežius Pranciškus, 2015, p. 10; Popiežius Aparesidos Marijos šventovèje: „Darykite, ką tik jis jums lieps“, 2013).

Šventasis Tèvas sako: „Kai užklumpa sunkumai, kai slegia problemos, kurių niekaip negalime išspręsti, kai liūdime ar esme sielvarto parblokšti, kai mums stinga džiaugsmo - eikime pas Švenčiausiąją Mergelę ir sakykime: „Neturime vyno. Vynas baigėsi. Pažvelki ị mane, pažvelk ị mano širdị, i sielą." Taip kreipkimès ị Mariją ir ji nueis pas savo Sūnų ir jam pasakys: „Pažvelk ị jị, pažvelk i ją. Jie neturi vyno.“ Paskui ji sugrị̌s pas mus ir tars: „Darykite, ką tik jis jums lieps“ (Popiežius, 2019). Taip Marija moko ịsiklausyti ị Jèzų, Motina kreipia savo Sūnaus link.

\subsection{Marija motiniškoje kančioje - „stovėjo“ (Jn 19, 25; Lk 23, 35.49)}

Marija gyvenimą priima tokị, koks jis yra: čia ir laimingos dienos, ir dramos. Ji priima ir tamsiausią naktị, kai jos Sūnus kalamas prie kryžiaus. Iki tos dienos Marija buvo kone dingusi iš Evangelijų pasakojimų. Šventieji evangelistai leidžia numanyti, kad tai romus atsitraukimas, nuščiuvimas Tẻvui paklūstančio Sūnaus slèpinio akivaizdoje. Tačiau Marija vẻl pasirodo lemiamu momentu, kai nemaža dalis draugų iš baimès yra pasitraukę (Popiežius Pranciškus, 2019, p. 97-98).

Evangelijos lakoniškos ir labai diskretiškos. Paprastu veiksmažodžiu nurodo Motinos buvimą: ji „stovejjo“ (Jn 19, 25). Nieko nepasakyta, kaip reagavo: verkè, neverkè. Nieko, nė menkiausios užuominos apie jos skausmą. Stovejjo ten, baisiausią, žiauriausią valandą ir kentejo kartu su Sūnumi. Marija „stovejjo“, tiesiog buvo ten. Marija „stovejjo“ gaubiama tirščiausių 
sutemų, bet vis dèlto „stovèjo“. Nepasitraukè. Marija yra visur, iki galo, kai tik reikia žvakès liepsnelès migloje ir tamsybèje. Ji irgi nežino prisikèlimo skirties, ką jos Sūnus dovanoja žmonijai, bet stovi išreikšdama ištikimybę Dievo planui (Popiežius Pranciškus, 2019, p. 98). Marija ne ta moteris, kuri dvasia palūžtų gyvenimiškų netikrumo situacijų akivaizdoje. Marija priima gyvenimą toki, koks jis yra. Taip yra iki pat tamsiausios Marijos nakties, kai jos Sūnus buvo prikaltas prie kryžiaus medžio (Popiežius Pranciškus, 2018 A, p. 74-75). Apaštalas Petras išsižadèjo Jėzaus, daugelis pabėgo, visi buvo persigandę (plg. Apd 1, 14), tačiau Marija ten tiesiog stovèjo, tarsi tai būtų visiškai natūralus dalykas.

Todèl popiežius Pranciškus sako: „Visi mylime ją kaip Motiną. Nesame našlaičiai. Turime Motiną danguje, kuri yra šventoji Dievo Motina. Ji mus moko laukimo dorybès net tuomet, kai viskas atrodo be prasmès. Ji visuomet pasitiki Dievo slépiniu, taip pat tuomet, kai jis, atrodo, aptemsta dèl blogio pasaulyje. Tegul tais sunkiais momentais Marija, Jėzaus mums dovanota Motina, sustiprina mūsų žingsnius. Tegul visuomet kalba mūsų širdžiai: „Kelkis! Pažvelk pirmyn, žvelk ị horizontą̨", - nes ji yra Vilties Motina“ (Popiežius Pranciškus, 2018 A, p. 76).

\section{Išvados}

Jėzus, Dievo Sūnus, Dievo atspindys, per kurị visa sukurta, susijungè su žeme įgydamas žmogišką pavidalą Mergelès Marijos įsčiose. Krikščionybeje kreipiamasi ị Mariją, kaip Motiną, prašant užtarimo ir globos. Popiežiaus Pranciškaus ypatingą pasišventimą Švč. Mergelei Marijai atskleidžia:

- $\quad$ pontifiko herbas, kur žvaigždė mėlyname skyde yra Švč. Mergelès Marijos simbolis, išreiškiantis jos išskirtinį vaidmenį Šventojo Tẻvo gyvenime;

- dažnas lankymasis bažnyčiose, kurios pašvęstos Marijos garbei, lankymasis Romos Didžiojoje Švč. Mergelès Marijos bazilikoje, kur meldžiasi ir padeda gèlių prie Marijos ikonos prieš kiekvieną kelionę ir grįžęs iš jos; 
- dėmesys Švč. Mergelès Marijos apsireiškimų vietoms: Lurdui, Fatimai, Gvadelupei ir Medžiugorjei, ị kurią paskiriamas nuolatinis apaštališkasis vizitatorius;

- $\quad$ kasdienè Rožinio malda;

- paskelbimas nutarimo ị Visuotini Romos kalendorių įtraukti Švč. Mergelès Marijos, Bažnyčios Motinos, minẻjimą ir šiuo titulu kasmet pagerbti Švenčiausiają Mergelę pirmadienị po Šventosios Dvasios Atsiuntimo iškilmès.

Dėmesys Švč. Mergelei Marijai popiežiaus Pranciškaus gyvenime skatina ypatingą dèmesị jai skirti ir savo mokyme. Šventasis Tẻvas, kalbėdamas apie Mariją, remiasi Evangelijų žinia:

- $\quad$ angelo apreiškimu Marijai - „malonėmis apdovanotoji“ (Lk 1, 28);

- Marijos apsilankymu pas Elzbietą - „tu labiausiai palaiminta“ (Lk $1,42)$;

- Marijos tyliu apmąstymu - ,dėmėjosi visus šiuos dalykus ir svarste juos savo širdyje“" (Lk 2, 19);

- Marijos kvietimu klausyti Jèzaus - „darykite, ką tik jis jums lieps“ (Jn 2, 5);

- Marijos motiniška kančia - „stovejjo“(Jn 19, 25; Lk 23, 35.49).

Popiežius Pranciškus neprideda nieko naujo prie to, kas pasakyta apie Švč. Mergelę Mariją Šventajame Rašte ir Bažnyčios Tradicijoje. Šventasis Tẻvas, mokydamas apie Mariją, tarsi pakartoja Šventojo Rašto ir Tradicijos žinią, akcentuodamas Marijos žmogišką normalumą, taigi ir artumą kiekvienam žmogui. Popiežius Pranciškus akcentuoja, kad Marija, rūpestingu žvilgsniu lydinti Jèzų, vykdantị savo misiją, visada rodo Sūnų Jèzų, o ne save. Ir paskutiniai Marijos žodžiai: „Darykite, ką tik jis jums lieps“ (Jn 2, 5) - tai kvietimas žvelgti ị Jèzų, Dievo Sūnų. 


\section{Literatūra}

Carello, R. (2018). Popiežius Pranciškus. 80 gyvenimo istorijų. Vilnius: Katalikų pasaulio leidiniai.

Congregation for Divine Worship and the Discipline of the Sacraments. (2018). Decree on the Celebration of the Blessed Virgin Mary Mother of the Church in the General Roman Calendar. Prieiga internete: $<$ http://www.vatican.va/roman_curia/congregations/ccdds/documents/rc_con_ccdds_doc_20180211_decreto-mater-ecclesiae_en.html > [žiūrèta 2018-10-30].

Gaeta, S. (2013). Dievas užklumpa netikètai. Popiežiaus Pranciškaus gyvenimas ir mintys. Vilnius: Katalikų pasaulio leidiniai.

Jonas Paulius II. (2002). Apaštališkasis laiškas ROSARIUM VIRGINIS MARIAE vyskupams, kunigams ir tikintiesiems apie šventaji rožinị. Prieiga internete: $<\mathrm{https}$ :// www.baznycioszinios.lt/old/bz0220/220dok.html> [žiūrèta 2019-07-30].

Lietuvos Vyskupų Konferencijos Liturgijos komisijos informacija dèl Švč. Mergelès Marijos, Bažnyčios Motinos, liturginio minèjimo. (2018). Bažnyčios žinios, Nr. 5, p. 15.

Marija, Bažnyčios Motina - Kristaus ir Bažnyčios slépinio supratimo raktas. (2018). Prieiga internete: <https://www.vaticannews.va/lt/baznycia/news/2018-05/marija-baznycios-motina-kristaus-ir-baznycios-slepinio-suprat.html $>$ [paskelbta 2018-05-17; žiūrèta 2019-07-15].

Popiežiaus Pranciškaus herbas ir moto. (2013). Prieiga internete: <http://www.bernardinai.lt/straipsnis/2013-03-19-popieziaus-pranciskaus-herbas-ir-moto/97492> [paskelbta 2013-03-19; žiūrèta 2019-07-22].

Popiežiaus Pranciškaus vizitas Lietuvoje. Kalbos. 2018 m. rugsèjo 22-23 d. (2018). Vilnius: Katalikų pasaulio leidiniai.

Popiežius Aparesidos Marijos šventoveje: „Darykite, ka tik jis jums lieps“. (2013). Prieiga internete: <http://www.bernardinai.lt/straipsnis/2013-07-24-popieziusaparesidos-marijos-sventoveje-darykite-ka-tik-jis-jums-lieps/104815> [paskelbta 2013-07-24; žiūrèta 2019-08-08].

Popiežius meldèsi prie Marijos „Salus populi romani“ atvaizdo. (2018). Prieiga internete: <https://www.vaticannews.va/lt/popiezius/news/2018-09/apastaliskoji-kelione-lietuva-salus-populi-romani.html> [paskelbta 2018-09-121; žiūreta 2019-07-31].

Popiežius Pranciškus. (2013). Enciklika LUMEN FIDEI apie tikèjima. Kaunas: Katalikų interneto tarnyba.

Popiežius Pranciškus. (2015). Žinia 24-osios Pasaulinės ligonių dienos (2016 m.) proga. Patikèti save gailestingajam Jèzui kaip Marija: „Darykite, ką tik jis jums lieps“ (Jn 2, 5). Bažnyčios žinios, Nr. 12, p. 9-10. 
Popiežius Pranciškus. (2016). Popiežiaus katechezės. Pirmas gailestingumo ženklas: Kana (Jn 2, 1-11). Bažnyčios žinios, Nr. 7, p. 23.

Popiežius Pranciškus. (2018, A). Džiaukitès viltyje. Trečiadienio katechezès apie vilti. Kaunas: Artuma.

Popiežius Pranciškus. (2018 B). Kai meldžiatès, sakykite: Tève mūsų. Vilnius: Katalikų pasaulio leidiniai.

Popiežius Pranciškus. (2019). Ave Marija. Marijos slèpinys Šventojo Tèvo akimis. Vilnius: Katalikų pasaulio leidiniai.

Popiežius Pranciškus: Rožinis yra lobis, kurị reikia atrasti. (2013). Prieiga internete: $<$ http:/www.bernardinai.1t/straipsnis/2013-05-02-popiezius-pranciskus-rozinis-yralobis-kuri-reikia-atrasti/100183> [paskelbta 2013-05-02; žiūrèta 2019-07-15].

Popiežius skiria nuolatinị apaštališkaji vizitatoriu Medžiugorje. (2018). Prieiga internete: <https:/www.vaticannews.va/lt/baznycia/news/2018-05/popiezius-skiria-ypatinga-apastaliskaji-vizitatoriu-medziugorje.html > [paskelbta 2018-05-31; žiūrèta 2019-07-15].

Popiežius. (2019). „,Darykite, ka tik jis jums lieps “. Prieiga internete: <https://www. vaticannews.va/lt/popiezius/news/2019-01/popiezius-sekmadienio-vidudieni-vynas-dziaugsmo-simbolis.html> [paskelbta 2019-01-20; žiūrèta 2019-08-08].

Pranciškus. (2018). Šio gyvenimo laimè. İtraukianti meditacija apie egzistenciją Žemeje. Vilnius: Baltos lankos.

Pranciškus. (2019). Pakrikštyti ir siunčiami: Kristaus Bažnyčios misija pasaulyje. Artuma, Nr. 7/8, p. 2, 6-7.

Ratzinger, J. (2010). Dievas ir pasaulis. Krikščionių tikejjimo paslaptys. Pokalbis su Peteriu Seewaldu. Vilnius: Alma littera.

Rožinio malda su popiežiumi Pranciškumi. (2018). Vilnius: Katalikų pasaulio leidiniai.

Šventasis Raštas. (2000). Vilnius: Lietuvos Biblijos draugija.

Šventasis Tẻvas Pranciškus. (2014). Apaštališkasis paraginimas EVANGELII GAUDIUM apie Evangelijos skelbima šiandieniniame pasaulyje. Kaunas: Katalikų interneto tarnyba.

Šventasis Tèvas Pranciškus. (2015). Enciklika LAUDATO SI’ apie rūpinimąsi bendraisiais namais. Kaunas: Kataliku interneto tarnyba.

Tornielli A. (2017). Kelyje. Pokalbiai su jo Šventenybe Pranciškumi. Vilnius: Baltos lankos.

Vallely P. (2015). Pope Francis. Untying the Knots. The Struggle for the Soul of Catholicism. New York: Bloomsbury. 


\section{ROLE OF THE BLESSED VIRGIN MARY IN POPE FRANCIS'S LIFE AND TEACHINGS}

\section{Remigijus Oželis}

Summary

Confession of Jesus, God's Son born of a woman, is at the centre of the Christian faith. Jesus, the Son of God, the revelation of God, through whom everything is created, united with the world when taking on a human body in the womb of Virgin Mary. The Blessed Virgin Mary is closely related to the Christian faith through her relation to Jesus. Christianity addresses Mary as Mother while asking for protection and care. This article discusses the role of the Blessed Virgin Mary in Pope Francis's life and teachings. Pope Francis's particular devotion to the Blessed Virgin Mary is revealed by:

- the coat of arms of the Pontificum where a star on the blue shield is a symbol of the Blessed Virgin Mary and expresses her exclusive role in the life of the Holy Father;

- $\quad$ his frequent visits to churches dedicated to Mary, especially to the basilica of Saint Mary Major in Rome for prayer and placing flowers in front of the icon of the Madonna before and after each foreign trip;

- his attention to the Blessed Virgin Mary's apparition sites: Lourdes, Fatima, Guadalupe, Medjugorje, where a permanent apostolic visitor has been appointed;

- $\quad$ his daily prayer of the Rosary;

- his announcement of the decision to include the memorial of the Blessed Virgin Mary, Mother of the Church, into the General Roman Calendar and to honour the Blessed Virgin by this title on the Monday after the celebration of the descent of the Holy Spirit (Pentecost) every year.

Special regard towards the Blessed Virgin Mary in the life of Pope Francis requires a special attention in His teaching as well. While speaking about Mary, the Holy Father refers to the Gospel: 
- the Annunciation - "highly favoured" (Luke 1:28);

- Mary's visit to Elizabeth - "blessed are you” (Luke 1:42);

- Mary's silent contemplation - "Mary kept all these things and pondered them in her heart" (Luke 2:19);

- Mary's call to listen to Jesus - "whatever he says to you, do it" (John 2: 5);

- Mary's maternal suffering - "stood" (John 19: 25; Luke 23: 35, 49).

Pope Francis adds nothing new to what has already been said about the Blessed Virgin Mary in the Holy Scripture and the Church Tradition. The Holy Father's teaching on Mary revisits the news of the Bible and Tradition with an emphasis on Mary's normality and therefore closeness to every person. Pope Francis stresses in His teaching that Mary, while carefully watching Jesus fulfilling His mission, always points to Her Son Jesus and not to Herself. 